\title{
Evaluation of Bioaerosols in Five Educational Hospitals Wards Air in Hamedan, During 2011-2012
}

\author{
Edris Hoseinzadeh ${ }^{1, *}$, Mohammad Reza Samarghandie ${ }^{2, *}$, Sayed Amir Ghiasian ${ }^{3}$, Mohammad \\ Yousef Alikhani ${ }^{4}$, Ghodratollah Roshanaie ${ }^{5}$ \\ ${ }^{1}$ Department of Environmental Health Engineering, Nutritional Health Research Center (NHRC), Faculty of Health, Lorestan University of Medical Sciences, Khorramabad, IR Iran \\ 2 Department of Environmental Health Engineering, Health Research Center, Faculty of Health, Hamadan University of Medical Sciences, Hamedan, IR Iran \\ 3 Department of Medical Parasitology and Mycology Department, School of Medicine, Hamadan University of Medical Sciences and Health Services, Hamedan, IR Iran \\ 4 Department of Microbiology, Faculty of Medicine, Hamadan University of Medical Sciences, Hamedan, IR Iran \\ 5 Department of Biostatistics, Faculty of Health, Hamadan University of Medical Sciences, Hamedan, IR Iran \\ ${ }^{*}$ Corresponding authors: Edris Hoseinzadeh, Department of Environmental Health Engineering, Faculty of Health, Lorestan University of Medical Sciences, Goldasht Street, Khor- \\ ramabad, Lorestan province, IR Iran. Tel: +98-6614208176, Fax: +98-6614204090, E-mail: hoseinzadeh@lums.ac.iredris-2009@live.com, Mohammad Reza Samarghandie, Depart- \\ ment of Environmental Health Engineering, Health research center, Faculty of Health, Hamedan University of Medical Sciences, Hamadan, IR Iran. Tel, Fax: +98-8118280026, E-mail: \\ mr.samarghany@umsha.ac.ir.
}

Received: February 12, 2013; Revised: April 28, 2013; Accepted: May 13, 2013

Background: Some human diseases such as tuberculosis, Legionnaires' disease and different forms of bacterial pneumonia, coccidioidomycosis, influenza, measles, and gastrointestinal illnesses are the result of exposure to bioaerosols. In addition, they are associated with some noninfectious airway diseases, such as allergies and asthma.

Objectives: In the education hospitals of Hamedan University of medical sciences, there were no previous qualitative and quantitative studies of bioaerosols in the air of wards, so in this study the quality and quantity of bioaerosols in hospital ward's air was investigated to establish a reference for future studies or measures.

Materials and Methods: In this cross sectional research, 30 wards in five educational hospitals of Hamadan city were studied. More than 180 air samples were collected from the hospitals. The samples were transferred to blood agar and Sabouraud medium and cultivated immediately. Type and number of colonies were determined in the laboratory. Bioaerosol concentrations were calculated in terms of cfu/ $\mathrm{m}^{3}$. After bioaerosols isolation, the isolates were identified by morphology of colony, Gram staining and by standard biochemical tests as required for bacterial or fungal bioaerosols. The SPSS software was used for data management. ANOVA and t-test statistical analyses were also used.

Results: As the results demonstrated, highest and lowest averages of bioaerosol density were obtained from Shahid Beheshti and Fatemieh Hospitals ( $36.18 \mathrm{cfu} / \mathrm{m}^{3}$ Vs. $24.03 \mathrm{cfu} / \mathrm{m}^{3}$ ), respectively. Highest and lowest concentrations of bioaerosols were found in Women1 and operating room wards of Fatemiyeh Hospital, respectively $\left(54.4 \mathrm{cfu} / \mathrm{m}^{3} \mathrm{VS} .13 .3 \mathrm{cfu} / \mathrm{m}^{3}\right.$ ). It appears that there had been no significant correlation between concentration of bioaerosols in the hospitals and available guideline values $(\mathrm{P}=0.3)$. The highest fungal populations were Penicelium spp. (32.06\%), Cladosporium spp. (20.5\%), Aspergillus fumigatus (14.61\%) and A. niger (7.43\%), respectively. The highest bacterial population was coagulase-negative staphylococci (32.49\%), Bacillus spp. (14.74\%), Micrococcus spp. (13.68\%) and Staphylococcus aureus (11.34\%), respectively.

Conclusions: Quantitative bioaerosols concentration in the air of some hospitals was more than the available guideline i.e. $30 \mathrm{cfu} / \mathrm{m}^{3}$. Bioaerosol density of all surveyed hospitals can relate to patients presence in wards and their visitors, incorrect ventilation, and probably inefficient disinfection. Most surveyed hospitals have no air treatment systems thus to reduce bioaerosol concentration, standard ventilation systems should designed and utilized.

Keywords: Bioaerosol; Hospital; Bacteria; Fungi; Air Pollution; Indoor

\section{Background}

Physical, chemical and biological properties of indoor air can affect health and welfare $(1,2)$. Indoor air quality is not easy to determine and control and may result in poor air quality for health workers and people involved in these environments (3). Indoor air of hospitals has a wide range of infectious microorganisms $(3,4)$. The microorganisms load from one department to another in a particular hospital, as well as distinct hospitals in a city or region can vary (5). Estimating density and diversity of microorganisms in the air of a hospital can be an indicator of whether such environments are dirty or clean. In

\section{Implication for health policy/practice/ research/medical education}

This is the first report on the isolation of fungal and bacterial bioaerosols from indoor air of hospital wards in Hamadan and can provide useful information for epidemiological studies of hospital acquired infections and airborne microorganism spread and control, and can be used to establish an applied reference for future studies or measures.

Copyright (C) 2013, Ahvaz Jundishapur University of Medical Sciences; Licensee Kowsar Ltd. This is an Open Access article distributed under the terms of the Creative Commons Attribution License (http://creativecommons.org/licenses/by/3.0), which permits unrestricted use, distribution, and reproduction in any medium, provided the original work is properly cited. 
addition, it is considered as a source of hospital-associated infections (6).

Microorganisms are the primary source of air contamination in indoor environments (7). Indoor air has a greater potential to endanger patients health than outdoor air Indoor aerosol types may have the ability to cause different levels of infection. Although many present biological substances in inhaled air are not considered as pollution but if their amount increases by several folds of their ambient amount, they can stimulate or poison people once inhaled (8). This pollution type includes materials such as air-borne particles, large molecules or volatile compounds that are both alive and released by living creatures. Some bioaerosols such as bacteria and viruses can multiply. Some others, such as pollen of plants and mite droppings may just be irritating $(9,10)$.

Motions of bioaerosols in the air depend on gravity, electromagnetism and the turbulence of air. Bioaerosol is a suspension of airborne particles that generally include live and dead bacteria or may be released from living organisms. Also bioaerosols can contain a variety of pathogenic and non-pathogenic viruses, fungi, high molecular weight allergens, endotoxins, fungal toxins, peptidoglycans, fungal spores and plant pollens $(9,10)$. Bioaerosols can be released through dust, dirt and water droplets in the environment (11). Contact with bioaerosols in different environments is associated with a risk of respiratory infectious diseases, acute toxic effects, allergies and cancer. Among indoor environments where bioaerosols are considered a problem, hospitals are of major concern as in these environments there are a wide range of people such as hospital and medical staff, service users, patients and visitors who can contact bioaerosols and inhale them $(11,12)$. Therefore, the presence of excess bioaerosol in hospitals air can be a serious health threat (13).

Perdelli et al. (14) studied fungi load in different wards of a hospital. They reported an average concentration of $19 \pm 19 \mathrm{cfu} / \mathrm{m}^{3}$ for fungi, where lowest concentration $(14 \pm$ $\left.12 \mathrm{cfu} / \mathrm{m}^{3}\right)$ was found in the operating room and highest concentration $\left(45 \pm 37 \mathrm{cfu} / \mathrm{m}^{3}\right)$ in the kitchen. Fugal genera that had the greatest number were Cladosporium spp., Aspergillus spp., Penicillium spp. and Rizopous, respectively. In a study conducted by Jabbari et al. (15) highest concentration of bioaerosol was reported for the infectious diseases ward $\left(300 \mathrm{cfu} / \mathrm{m}^{3}\right)$ and the lowest mean concentration of bioaerosol was found at the Ear, Nose and Throat (ENT) and eye surgery wards $\left(94 \mathrm{cfu} / \mathrm{m}^{3}\right)$. The highest percentages of fungi found in the air of hospitals were Penicillium spp.(36.36\%), Cladosporium spp. (24.74\%), Aspergillus niger (17.97\%), Rizopous (10.57\%) and A. flavus (2.74\%), respectively. As some previous studies have shown, exposure to a high density of bacterial bioaerosols can cause asthma and rhinitis $(16,17)$, hypersensitivity pneumonitis (17) and sick building syndrome (16). Among bacterial bioaerosols, those such as Bacillus sp., Streptomyces albus, Pantoeaag glomerans, Pseudomonas chlororaphis, Arthro- bacter globiformis, Thermoactinomycetes vulgaris, and Corynebacterium sp. have potential allergenic or immunotoxic characteristics and are a probable cause of airborne infectious illnesses.

Most bioaerosols are non-pathogenic and only cause infection or illness in people with impaired or susceptible immune systems (15). Many researchers have confirmed that hospitals (all of wards) as a source for propagation and transmission of acquired infections and bioaerosols are at high risk. Therefore, knowledge about the prevalence of bacterial flora in hospitals and understanding types of infections and allergies caused by bioaerosols is of utmost importance. Microbial control in hospital environments and its air can also play a major role in the prevention of cross infection.

\section{Objectives}

This study obtains quantity of air pollution in view of bioaerosols, so it can show pollution levels and we can compare it with the guidelines, standards and similar studies that will help in understanding of contamination; as quantitative studies, due to say pollution levels and compare that with the guidelines, standards and similar studies will help in understanding of contamination; the aim of this study was to determine the density and diversity of bioaerosols in educational hospitals of Hamedan in 2012.

\section{Materials and Methods}

This cross-sectional study was performed for five educational hospitals under supervision of Hamedan University of Medical Sciences in Hamedan, during 2012. Due to budget constraints, only 6 wards from each hospital were studied to determine density and type of bioaerosol. Selecting hospital wards took place according to services provided by each hospital, importance of ward according to the type of hospitalized patients and proposal of infection control and environmental health offices located in each studied hospital. Studied hospitals and their geographical locations are demonstrated by Figure 1 .

\subsection{Bioaerosols Density Determination}

The filtration method was used for bioaerosol sampling (17). This is one of the methods recommended by the Bioaerosols Committee of American Conference of Industrial Hygienists (ACGIH) and has been utilized by Ghorbani et al. (9) and Mohammadian et al. (11). Used instruments in this phase of the study were: a pump sampler, Teflon filter holder with a $47 \mathrm{~mm}$ diameter, sterile mixed cellulose ester filter with support pad (MCES; 0,45 $\mu \mathrm{m}$ pore size, S-Pak sterile, Merck Millipore), disposable sterile petri plates (M/s GSV Enterprises), Sabouraud dextrose agar and blood agar culture medium (Merck, Germany). Before sampling, all required equipment disinfected by $70 \%$ alcohol at first then autoclaved at the standard tempera- 
ture and pressure for 30 minutes. Next, all instruments were taken to hospitals in sterile packages.

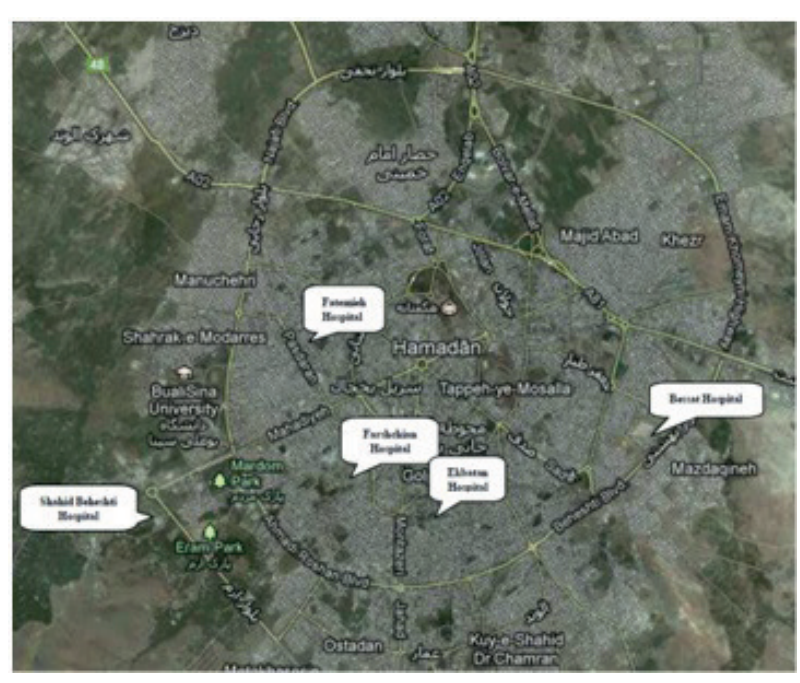

Figure 1. Location of Studied Hospitals for Bioaerosol Sampling in This Study

In the hospital and in selected wards, samplers were prepared and samples were obtained. To increase accuracy, a number of environmental and laboratory samples were collected as control samples. Previously, using ACGIH guidelines and doing some pre tests, $10 \mathrm{~L} / \mathrm{min}$ and 30 min were selected as the sampling strategy. Sampling was done at 1.2 to 1.8 meters above the ground (1.5 m for all samples) with more than a meter away from walls and obstacles. Finally, 36 samples were taken from each ward. 18 samples were taken to check for fungal bioaerosol contamination and 18 samples for bacterial bioaerosols. Two sampling systems with same conditions were used for bacterial and fungal sampling, simultaneously.

Along with sampling, some parameters such as air temperature, humidity and air velocity (every 10 minutes) were measured and recorded in a prepared checklist. Before and after each sampling event the flow rate of the sampler was checked and calibrated using a rotameter (Skc Inc. Houston, UA). If the difference between the initial and final flow rates was greater than $10 \%$, the sample was rejected. At the end of the sampling, with standard conditions, filters were reversely placed on Sabouraud dextrose agar and Blood agar culture medium (for fungal and bacterial bioaerosol, respectively). They were transferred to the laboratory at standard conditions. Inoculated plates were incubated at $37^{\circ} \mathrm{C}$ for $48-72 \mathrm{~h}$, after which type and number of colonies per plate was determined. On each plate labels were attached (including sample code, hospital name, department name, sampling point). Volume of sampled air was corrected based on pressure and temperature of the sampling wards $(1,2,9)$. The volume of sampled air was corrected using the following equation: P1 V1/T1 = P2 V2/T2

Where $\mathrm{P}$ is atmospheric pressure, $\mathrm{V}$ is volume of sampled air and $\mathrm{T}$ is sampled air temperature. Where, one and two indices represent standard conditions and sampling conditions, respectively. Temperature and humidity at the sampling wards were measured using a digital hygro-thermometer (Testoterm, Germany) and the air velocity was measured using an anemometer (Utron, AM4201) (Fisons Scientific, Loughborough, UK). All measurements were made in triplicates and the averages were used. With volume of sampled air and the number of colonies cultured, bioaerosols densities were calculated in terms of number of colonies counted in a cubic meter of $\operatorname{air}\left(\mathrm{cfu} / \mathrm{m}^{3}\right)$.

\subsection{Bioaerosols Type Determination}

To assess cognitive bacteria, a microbiological expert evaluated all incubated plates in term of colony growth, morphology, color and appearance. For staining and microscopic examination of each sample, one slide was prepared. Bacteria were studied using their shape (cocci and bacilli) and by the Gram stain method. Plates containing fungus were incubated at 25 to $27^{\circ} \mathrm{C}$ temperatures for 72 to 120 hours. After incubation, numbers of formed colonies on the plates were counted. The isolated fungi were primarily identified by their colony morphology and microscopic structures. To achieve exact fungus identification, previously reported identification methods such as tested mount and slide culture were used $(7,15,18)$. The results of the experiments were analyzed using the SPSS (ANOVA and t-test statistical analyses) and Excel software.

\section{Results}

In the present study 6 wards from each of the five educational hospitals in Hamadan i.e., 180 samples evaluated for bioaerosol analysis and bioaerosol concentration were reported in term of $\mathrm{cfu} / \mathrm{m}^{3}$. For each sample, bacterial and fungal bioaerosols were identified. Average bioaerosol concentration based on each hospital and ward is presented in Table 1. Physical characteristic of sampled air were $25.83 \pm 2.67^{\circ} \mathrm{C}, 35.32 \pm 6.66 \%$ and $1.52 \pm 0.27 \mathrm{fts}-1$ for air temperature, humidity and air velocity in the sampling position, respectively. According to Table 1, greatest bioaerosol concentration was detected for the emergency ward of Besat hospital (24.3 cfu/ $\mathrm{m}^{3}$ bacterial bioaerosol) and lowest for the women 3 and emergency wards of Fatemieh hospital (3.3 cfu/ $\mathrm{m}^{3}$ fungal bioaerosol).

Total averages of bioaerosol concentration for all surveyed hospitals were 160.6 and $12.56 \mathrm{cfu} / \mathrm{m}^{3}$ for bacterial and fungal bioaerosols, respectively. There was no significant difference between the mean bacterial bioaerosol 
Hoseinzadeh E et al.

\begin{tabular}{|c|c|c|c|c|c|c|c|}
\hline \multirow{2}{*}{$\begin{array}{l}\text { Hospital Name } \\
\text { Farshchian Hospital }\end{array}$} & \multicolumn{7}{|c|}{ Studied Wards for Each Hospital } \\
\hline & ward & isolation & emergency & eye & infectious & operation room & ICU \\
\hline & Mean bacterial & 7.8 & 17.8 & 11.1 & 18.9 & 13.3 & 12.2 \\
\hline & Mean fungal & 16.7 & 16.7 & 15.6 & 11.1 & 7.8 & 6.7 \\
\hline \multirow[t]{3}{*}{ Ekbatan Hospital } & ward & isolation & women & $\mathrm{CCU}$ & emergency & operation room & $\begin{array}{l}\text { nurs- } \\
\text { es' sta- } \\
\text { tion }\end{array}$ \\
\hline & Mean bacterial & 10 & 20.2 & 10 & 13.4 & 12.2 & 23.4 \\
\hline & Mean fungal & 13.4 & 5.6 & 11.1 & 5.6 & 20 & 8.9 \\
\hline \multirow[t]{3}{*}{ Fatemieh Hospital } & ward & isolation & women 1 & women 3 & emergency & operation room & $\begin{array}{l}\text { neona- } \\
\text { tal } 1\end{array}$ \\
\hline & Mean bacterial & 13.2 & 20 & 12.3 & 13.3 & 7.8 & 13.4 \\
\hline & Mean fungal & 14.2 & 34.4 & 3.3 & 3.3 & 5.5 & 3.4 \\
\hline \multirow[t]{3}{*}{$\begin{array}{l}\text { Shahid Beheshti } \\
\text { Hospital }\end{array}$} & ward & isolation & emergency & nurses' station & ICU & operation room & $\begin{array}{l}\text { ne- } \\
\text { phrol- } \\
\text { ogy }\end{array}$ \\
\hline & Mean bacterial & 22.3 & 16.5 & 22.3 & 16.6 & 22.5 & 22.5 \\
\hline & Mean fungal & 26.8 & 18.7 & 16.8 & 11.1 & 5.6 & 11.2 \\
\hline \multirow[t]{3}{*}{ Bessat Hospital } & ward & isolation & emergency & nurses' station & pediatric & operation room & ICU \\
\hline & Mean bacterial & 19.9 & 24.3 & 14.6 & 20.1 & 11.1 & 18.9 \\
\hline & Mean fungal & 15.5 & 7.7 & 12.4 & 14.5 & 21 & 21.3 \\
\hline
\end{tabular}

\begin{tabular}{|c|c|c|c|c|c|c|c|}
\hline \multirow{2}{*}{$\begin{array}{l}\text { Hospital Names } \\
\text { Farshchian Hospital }\end{array}$} & \multicolumn{6}{|c|}{ Studied Wards For Each Hospital } & \multirow{2}{*}{$\begin{array}{l}\text { Total } \\
\text { Average }\end{array}$} \\
\hline & isolation & emergency & operation room & infectious & eye & ICU & \\
\hline & 24.5 & $34.4^{\mathrm{a}}$ & 21.1 & 30 & 26.7 & 18.9 & 25.93 \\
\hline \multirow[t]{2}{*}{ Ekbatan Hospital } & isolation & emergency & operation room & women & $\mathrm{CCU}$ & nurses' station & \\
\hline & 23.4 & 19 & $32.2^{\mathrm{a}}$ & 25.8 & 21.1 & $32.3^{\mathrm{a}}$ & 25.63 \\
\hline \multirow[t]{2}{*}{ Fatemieh Hospital } & isolation & emergency & operation room & women 1 & women 3 & neonatal 1 & \\
\hline & 27.4 & 16.7 & 13.3 & $54.4^{\mathrm{a}}$ & 15.6 & 16.8 & 24.03 \\
\hline \multirow{2}{*}{$\begin{array}{l}\text { Shahid Beheshti } \\
\text { Hospital }\end{array}$} & isolation & emergency & operation room & ICU & nurses' station & nephrology & \\
\hline & $49.1^{\mathrm{a}}$ & $35.3^{\mathrm{a}}$ & 28.2 & 27.7 & $39.1^{\mathrm{a}}$ & $37.7^{\mathrm{a}}$ & $36.18^{\mathrm{a}}$ \\
\hline \multirow[t]{2}{*}{ BessatHospital } & isolation & emergency & operation room & ICU & nurses' station & pediatric & \\
\hline & $35.4^{\mathrm{a}}$ & $32^{\mathrm{a}}$ & $32.1^{\mathrm{a}}$ & $31.2^{\mathrm{a}}$ & 27 & $35.6^{\mathrm{a}}$ & $32.22^{\mathrm{a}}$ \\
\hline
\end{tabular}

\footnotetext{
${ }^{\mathrm{a}}$ Underline and bold denote cases more than $30 \mathrm{cfu} / \mathrm{m}$
}

concentrations and studied hospital wards (ANOVA, P = 0.25 ), but there was a significant difference between fungal bioaerosol concentration and studied hospital wards $(\mathrm{P}<0.001)$. To determine whether the obtained results for bioaerosol concentration in hospital wards, is acceptable or not based on available guidelines, it is necessary to compare them with the guideline values. Currently there is no definitive standard or guideline accepted by all institutions or organizations. Given values by some organizations are considered as guidelines or proposed standards. For the present study, $30 \mathrm{cfu} / \mathrm{m}^{3}$ was used as a guideline value for comparison. In Table 2, the results for the overall density of bioaerosols are presented. In this table, values more than the proposed guideline are denoted by an underline. According to Table 2, the highest and lowest bioaerosol concentrations were in women1 and operation room wards of Fatemieh hospital $(54.4 \mathrm{cfu} / \mathrm{m}$ ${ }^{3} \mathrm{VS} 13.3 \mathrm{cfu} / \mathrm{m}^{3}$ ). Results of the statistical analysis which compared the overall bioaerosol density in studied hospitals with $30 \mathrm{cfu} / \mathrm{m}^{3}$, showed no significant differences $(\mathrm{P}=0.3)$ (Table 3$)$. 
Table 3. Properties of Studied Hospital Wards of the Present Study (Ventilation, Chemical Disinfectant and Number of bed for Each Ward)

\begin{tabular}{|c|c|c|c|c|c|c|c|}
\hline \multirow{2}{*}{$\begin{array}{l}\text { Hospital } \\
\text { Names } \\
\text { Farshchian } \\
\text { Hospital }\end{array}$} & \multicolumn{7}{|c|}{ Studied Wards for Each Hospital } \\
\hline & studied wards & isolation & emergency & $\begin{array}{l}\text { operation } \\
\text { room }\end{array}$ & infectious & eye & ICU \\
\hline & $\begin{array}{l}\text { Ventilation } \\
\text { system }\end{array}$ & HVAC $^{\mathrm{a}}$ & Natural & HVAC & Natural & Natural & HVAC \\
\hline & Disinfectant & White King & White King & White King & White King & White King & Deconex ${ }^{b}$ \\
\hline & $\begin{array}{l}\text { Number of } \\
\text { Bed }\end{array}$ & 6 & 15 & - & 34 & 30 & 8 \\
\hline \multirow[t]{4}{*}{$\begin{array}{l}\text { Ekbatan } \\
\text { Hospital }\end{array}$} & studied wards & isolation & emergency & $\begin{array}{l}\text { operation } \\
\text { room }\end{array}$ & women & CCU & $\begin{array}{l}\text { nurses' sta- } \\
\text { tion }\end{array}$ \\
\hline & $\begin{array}{l}\text { Ventilation } \\
\text { system }\end{array}$ & $\begin{array}{l}\text { HVAC \& } \\
\text { Natural }\end{array}$ & $\begin{array}{l}\text { HVAC \& } \\
\text { Natural }\end{array}$ & HVAC & $\begin{array}{l}\text { HVAC \& } \\
\text { Natural }\end{array}$ & $\begin{array}{l}\text { HVAC \& Natu- } \\
\text { ral }\end{array}$ & $\begin{array}{l}\text { HVAC \& } \\
\text { Natural }\end{array}$ \\
\hline & Disinfectant & $\begin{array}{l}\text { Deconex+ } \\
\text { White King }\end{array}$ & $\begin{array}{l}\text { Deconex+ } \\
\text { White King }\end{array}$ & $\begin{array}{l}\text { Deconex+ } \\
\text { White King }\end{array}$ & $\begin{array}{l}\text { Deconex+ } \\
\text { White King }\end{array}$ & Salon+deconex & $\begin{array}{l}\text { Deconex+ } \\
\text { White King }\end{array}$ \\
\hline & $\begin{array}{l}\text { Number of } \\
\text { Bed }\end{array}$ & 2 & 9 & 11 & 11 & 33 & - \\
\hline \multirow[t]{4}{*}{$\begin{array}{l}\text { Fatemieh } \\
\text { Hospital }\end{array}$} & studied wards & isolation & emergency & $\begin{array}{l}\text { operation } \\
\text { room }\end{array}$ & women 1 & women 3 & neonatal 1 \\
\hline & $\begin{array}{l}\text { Ventilation } \\
\text { system }\end{array}$ & $\begin{array}{l}\text { HVAC \& } \\
\text { Natural }\end{array}$ & $\begin{array}{l}\text { HVAC \& } \\
\text { Natural }\end{array}$ & $\begin{array}{l}\text { HVAC \& } \\
\text { Natural }\end{array}$ & $\begin{array}{l}\text { HVAC \& } \\
\text { Natural }\end{array}$ & $\begin{array}{l}\text { HVAC \& Natu- } \\
\text { ral }\end{array}$ & $\begin{array}{l}\text { HVAC \& } \\
\text { Natural }\end{array}$ \\
\hline & Disinfectant & $\begin{array}{l}\text { Deconex+ } \\
\text { White King }\end{array}$ & $\begin{array}{l}\text { Deconex+ } \\
\text { White King }\end{array}$ & $\begin{array}{l}\text { Deconex+ } \\
\text { White King }\end{array}$ & $\begin{array}{l}\text { Deconex+ } \\
\text { White King }\end{array}$ & $\begin{array}{l}\text { Deconex+ } \\
\text { White King }\end{array}$ & $\begin{array}{l}\text { Deconex+ } \\
\text { White King }\end{array}$ \\
\hline & $\begin{array}{l}\text { Number of } \\
\text { Bed }\end{array}$ & 1 & 9 & - & 18 & 15 & 11 \\
\hline \multirow{4}{*}{$\begin{array}{l}\text { Shahid- } \\
\text { Beheshti } \\
\text { Hospital }\end{array}$} & studied wards & isolation & emergency & $\begin{array}{l}\text { operation } \\
\text { room }\end{array}$ & ICU & nurses' station & nephrology \\
\hline & $\begin{array}{l}\text { Ventilation } \\
\text { system }\end{array}$ & HVAC & $\begin{array}{l}\text { HVAC \& } \\
\text { Natural }\end{array}$ & HVAC & $\begin{array}{l}\text { HVAC \& } \\
\text { Natural }\end{array}$ & $\begin{array}{l}\text { HVAC \& Natu- } \\
\text { ral }\end{array}$ & $\begin{array}{l}\text { HVAC \& } \\
\text { Natural }\end{array}$ \\
\hline & Disinfectant & $\begin{array}{l}\text { Deconex+ } \\
\text { White King }\end{array}$ & $\begin{array}{l}\text { Deconex+ } \\
\text { White King }\end{array}$ & $\begin{array}{l}\text { Deconex+ } \\
\text { White King }\end{array}$ & $\begin{array}{l}\text { Deconex+ } \\
\text { White King }\end{array}$ & $\begin{array}{l}\text { Deconex+ } \\
\text { White King }\end{array}$ & $\begin{array}{l}\text { Deconex+ } \\
\text { White King }\end{array}$ \\
\hline & $\begin{array}{l}\text { Number of } \\
\text { Bed }\end{array}$ & 2 & 9 & 1 & 5 & - & 14 \\
\hline \multirow[t]{4}{*}{$\begin{array}{l}\text { Bessat Hos- } \\
\text { pital }\end{array}$} & studied wards & isolation & emergency & $\begin{array}{l}\text { operation } \\
\text { room }\end{array}$ & ICU & nurses' station & pediatric \\
\hline & $\begin{array}{l}\text { Ventilation } \\
\text { system }\end{array}$ & HVAC & HVAC & HVAC & HVAC & HVAC & HVAC \\
\hline & Disinfectant & $\begin{array}{l}\text { Deconex+ } \\
\text { White King }\end{array}$ & $\begin{array}{l}\text { Deconex+ } \\
\text { White King }\end{array}$ & $\begin{array}{l}\text { Deconex+ } \\
\text { White King }\end{array}$ & $\begin{array}{l}\text { Deconex+ } \\
\text { White King }\end{array}$ & $\begin{array}{l}\text { Deconex+ } \\
\text { White King }\end{array}$ & $\begin{array}{l}\text { Deconex+ } \\
\text { White King }\end{array}$ \\
\hline & $\begin{array}{l}\text { Number of } \\
\text { Bed }\end{array}$ & 1 & 27 & 6 & 23 & - & 26 \\
\hline
\end{tabular}

\footnotetext{
a Air Conditioning system

b deconex® $50 \mathrm{FF}$
}

As Figure 2 shows, highest percentages of detected fungal genera are Penicillium spp.(32.06\%), Cladosporium spp. (20.5\%), A. fumigatus (14.61\%), A. niger (7.43\%), respectively. Based on the results presented by Figure 3, greatest percentage of isolated bacteria were coagulase-negative staphylococci (32.49\%), Bacillus spp. (14.74\%), Micrococcus spp.(13.68\%) and Staphylococcus aureus (11.34\%), respectively. 


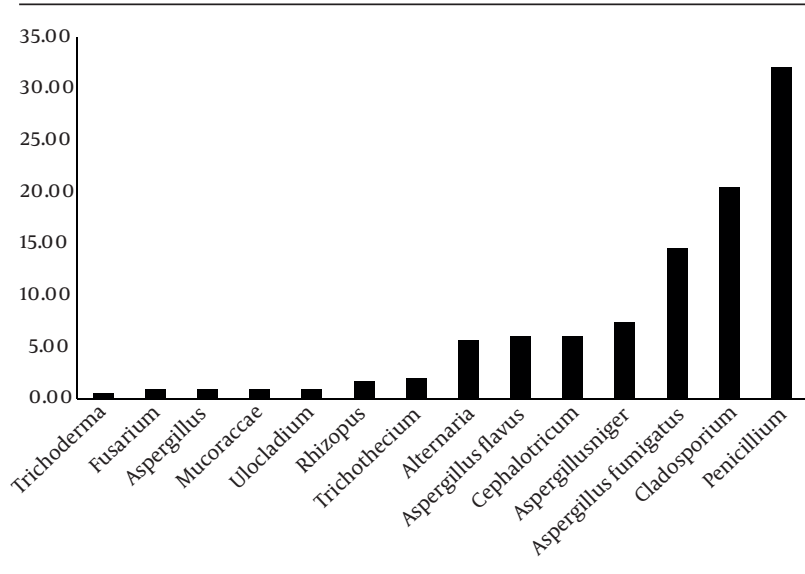

Figure 2. Percentage of Detected Fungus in Bioaerosol for Studied Hospitals

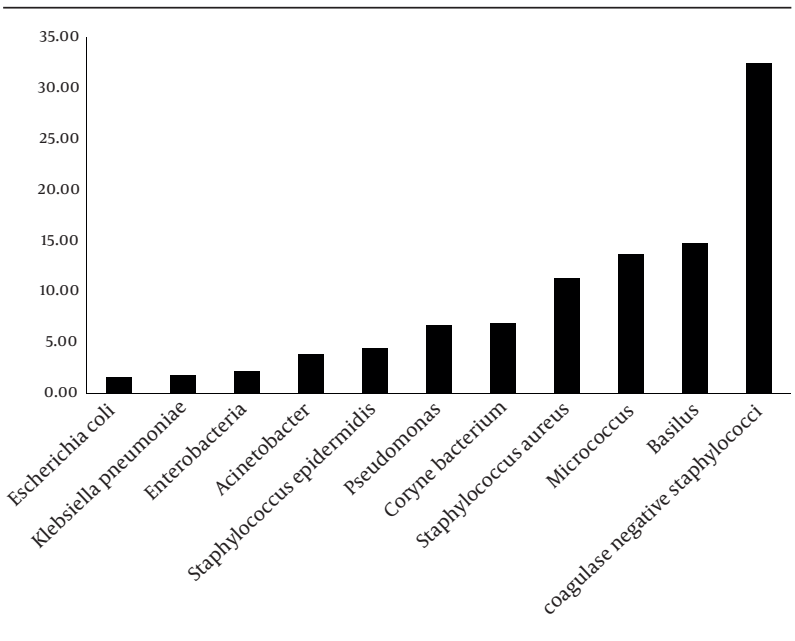

Figure 3. Percentage of Detected Bacterium in Bioaerosol for Studied Hospitals

\section{Discussion}

In this study, 11 bacterial species and 14 fungal genera were identified from bioaerosol evaluation in surveyed hospitals. Comparison of diagnosed bioaerosol types by the present study indicates that the results are similar to previous studies. Jafal and colleagues (4) in their study identified S. aureus, Coccus, Micrococcus, Alpha-hemolytic Streptococcus, Diphtheroid bacilli, Gram negative bacilli and other bacillus genera, Streptomyces and a variety of bacteria and fungi from men, women, children, surgery, ICU and operation room wards, respectively. The results of the present study for identified bacterial species were similar to Jafal et al. bacteriological results. Their quantitative results of bacteriological studies revealed that children and women wards had the highest bioaerosol concentration, respectively. One of the probable reasons can be the high number of patients that refer to these wards (3).

In the present study, the highest bacterial bioaerosol concentration was found for the emergency ward of Bessat hospital $\left(24.3 \mathrm{cfu} / \mathrm{m}^{3}\right)$. The overall density of bioaerosol was the highest in women 1 ward in Fatemieh hospital $\left(54.4 \mathrm{cfu} / \mathrm{m}^{3}\right)$. In the emergency and women wards of hospitals there are some non-sterile devices such as personal belongings of patients and visitors, as well as overcrowding of patients and this may be the reason why the emergency ward may have a high diversity and density of bioaerosols (3). Similar studies have also noted these factors, e.g. Jabbari et al. (15) found women's ward as the most contaminated. The researchers said that overcrowding of patient in this ward might be the main cause of these findings. In the present study, the most identified fungal genera was Penicillium spp. in the women's ward, which is consistent with the Jabbari et al. study.

Abdollahi's study (5) found that the quantity of fungal bioaerosol concentration in the ICU and coronary care unit, was higher than the other wards. They considered this as a risk factor for the sensitive patients admitted to these wards. In a study performed to assess fungal bioaerosol concentration of wards air carried out in Italy (14), Penicillium spp., Cladosporium spp. and Aspergillus were reported as the most common fungal bioaerosols, respectively. Penicillium and Aspergillus fungal bioaerosols were reported at 26 to $78 \mathrm{cfu} / \mathrm{m}^{3}$ for the studied wards. In general, we can say that the results of the present study are similar to other similar studies, qualitatively and quantitatively.

Bioaerosol density in the operating room has been minimal. This can be because of the high level of health standards, as well as disinfectant and air purification systems such as ultraviolet light application in this ward (3). The most frequent bacterial bioaerosol for all studied hospital wards was coagulase-negative Staphylococcus. Coagulase-negative staphylococci (CoNS) are part of the usual flora of human skin. These organisms have a relatively low virulence but are increasingly recognized as agents of clinically significant infection of the bloodstream and other sites especially for high-risk groups (19). Staphylococci are quite resistant to desiccation and high-osmotic conditions. These properties make their continued existence in the environment, growth in food, and communicability possible.

Botelho et al. (19) in their study isolated coagulase-negative staphylococci from hospital indoor air. They collected 108 coagulase-negative staphylococci (CoNS) from hospital indoor air. S. epidermidis $(\mathrm{n}=27)$ and S. haemolyticus $(\mathrm{n}=17)$ were the most frequent species identified. Thus they concluded that some airborne isolates display virulence profiles and levels of biofilm accumulation similar to those found in patient isolates. Hospital indoor air can be an important route for transmission of CoNS isolates. The most frequent species of fungal bioaerosols, identified by Perdelli et al. (14), from hospital indoor air 
were Cladosporium spp., Aspergillus spp., Penicillium spp. and Rhizopus, respectively. In addition, the most frequent species of fungal bioaerosols, identified by Panagopoulou et al. (20) among fungal genera, was Aspergillus spp.

Frequency and diversity of fungi in different published studies are not identical. Various factors such as the sampling season, impact of outdoor on hospital indoor air, type of admitted patient, type of ventilation system and its effectiveness, and efficiency of disinfection can affect frequency and diversity of isolated fungi from indoor hospital air. Kinti studied ophthalmology wards air for fungal bioaerosol evaluation. He found that Penicillium spp., Aspergillus spp., Mucor and Alternaria were the most frequent fungi isolates, respectively. His quantitative results were close to that of thepresent study.

According to Table 2, the highest overall bioaerosol density was obtained for Shahid Beheshti and Bessat hospitals, respectively. These two hospitals have specialized services and they are the main hospitals of Hamedan, thus their high bioaerosol density may be because a large quantity of patients are referred to these hospitals. In addition, the location of these two hospitals is around the city (with opposite latitudes, geographically). Therefore, these hospitals' indoor air quality may be affected by the outdoor air quality (21). Field observations showed that Shahid Beheshti hospital had no central and standard ventilation system for purification of hospital wards indoor air (Table 3). To supply indoor air, Shahid Beheshti hospital wards, use natural ventilation without pretreatment. This means that external air flows inwards through opened windows because of pressure or temperature differences. Also, some of the bioaerosol density may be because the hospital is located next to a green area.

Some researchers have addressed the impact of outdoor air on indoor air of closed places such as hospitals $(11,22)$. Although the Bessat Hospital had standard central ventilation, yet the existing system does not operate probably. For more detailed information, the system should be reviewed in terms of ventilation system design and operation. Some patient activities such as talking, walking in wards, sneezing and coughing cause an increase in emission and bioaerosol density of hospitals ward air $(22,23)$. Okhunoya et al. (23) concluded that patients and their activities might be factors affecting the concentration of bioaerosl density of indoor air.

Measurements of physical parameters such as airflow rate, showed that airflow was generally lower than $2 \mathrm{fts}-1$ for all studied wards. In most wards airflow rate was zero or near to zero. Poor air flow rate does not allow movement, emission and dispersal of microorganisms from their resources. One way to prevent the entry of airborne pathogens is to control the positive inside air pressure. As airflow rate was zero at most hospital wards, thus there was no positive pressure. This results in the entry of airborne pathogens from the outside. Washing and disinfecting of ward floor, walls and some of the equipment can increase humidity therefore facilitating growth and survival of microorganisms. However, there was no disinfectant mechanism for indoor air of wards (Table 3), only for the operation room. Mean bioaerosol density of operation room's air was more than $30 \mathrm{cfu} / \mathrm{m}^{3}$ in a study performed by Choobineh et al. ( 7 ) and Jabari et al. ( 15 ). They concluded that ventilation defects, as well as unsuitable disinfection were the main cause of high bioaerosol density of surveyed wards.

As the results show, bioaerosol density of some hospital wards was more than $30 \mathrm{cfu} / \mathrm{m}^{3}$. Most studied hospitals did not have air treatment systems. Therefore, should be taking measures to improve design and equipment installation. Finally, it is suggested that hospital managers attempt to qualitatively and quantitatively evaluate indoor air of hospitals periodically, and they should place and use air purification equipment in hospitals during the building stage.

\section{Acknowledgements}

This article is the result of a research project approved by the Research Center for Health Sciences, Hamedan. The authors would like to thank the Vice-Chancellor of Research and Technology, Hamedan University of Medical Sciences, who supported this study, financially. In addition, we specially thank Mr. Moghadam Shakib and Mrs. Karimkhani, who are the Microbiology and Mycology Laboratory instructors, respectively.

\section{Authors' Contribution}

None declared.

\section{Financial Disclosure}

None declared.

\section{Funding/Support}

None declared.

\section{References}

1. Hoseinzadeh Edris, Samarghandi Mohammad Reza, Ghorbani Shahna Farshid, Chavoshi Ebrahim. Isoconcentration mapping of particulate matter in Hamedan intercity bus stations. Water Environ J. 2012.

2. Hosseinzadeh E, Samarghandi MR, Faghih MA, Roshani G, Hashemi Z, Shahidi R. Study of volatile organic materials concentrations (BTEX) and electromagnetic fields in printing and copying centers in Hamadan. Jundishapur J Health Sci. 2012;4(3):25-34.

3. Ekhaise FO, Ighosewe OU, Ajakpovi OD. Hospital indoor airborne microflora in private and government owned hospitals in Benin City, Nigeria. World J Med Sci. 2008;3(1):19-23.

4. Jaffal AA, Banat IM, El Mogheth AA, Nsanze H, Bener A, Ameen AS. Residential indoor airborne microbial populations in the United Arab Emirates. Environ Int. 1997;23(4):529-533.

5. Abdolahi AR, Mehrazma M. Concurrence of Nosocomial Infections with Microorganisms Spreading in the Air of Hospital Wards. Med Lab J. 2009;3(2)

6. Borghesi A, Stronati M. Strategies for the prevention of hospitalacquired infections in the neonatal intensive care unit. J Hosp Infect. 2008;68(4):293-300.

7. Choobineh A, Rostam R, Tabatabae SH. Assessment of Bioaero- 
solsTypes and Concentration inAmbientAirof Shiraz University of Medical Sciences Educational Hospitals in 2008. Iran Occupational Health J. 2009;6(2):69-76.

8. de Souza AL, Seguro AC. Gram staining: an unexplored diagnos tic tool for diagnosis of meningococcal infection in the developing world. J Emerg Med. 2009;37(1):83-4.

9. Ghorbani-Shahna F, Joneidi-Jafari A, Yousefi-Mashouf R, Mohseni M, Shirazi J. [Type and Concentration of Bioaerosols in the Operating Room of Educational Hospitals of Hamadan University of Medical Sciences and Effectiveness of Ventilation Systems, in Year 2004]. Sci J Hamadan Univ Med Sci. 2006;13(2):64-70.

10. Harrison J, Pickering CA, Faragher EB, Austwick PK, Little SA, Lawton L. An investigation of the relationship between microbial and particulate indoor air pollution and the sick building syndrome. Respir Med.1992;86(3):225-35.

11. Mahmmodian M, Movaheddi MA. [Assessment of biological agents in the air of different wards in Imam Khomayni and Shahid Zare hospitals in Sari, 2007]. J North Khorasan Univ Med Sci. 2010;2(2,3):51-8.

12. Lim Taesub, Cho Jinkyun, Kim Byungseon Sean. The predictions of infection risk of indoor airborne transmission of diseases in high-rise hospitals: Tracer gas simulation. Energy and Buildings. 2010;42(8):1172-1181.

13. Knibbs LD, Morawska L, Bell SC, Grzybowski P. Room ventilation and the risk of airborne infection transmission in 3 health care settings within a large teaching hospital. Am J Infect Control. 2011;39(10):866-72.

14. Perdelli F, Cristina ML, Sartini M, Spagnolo AM, Dallera M, Ottria $\mathrm{G}$, et al. Fungal contamination in hospital environments. Infect Control Hosp Epidemiol. 2006;27(1):44-7.
15. Jabari H, Nadafi K, Nabizadeh R, Tabaraie Y, Azam-Solgi A, Azizifar M. A Qualitative and Quantitative Survey on Air-Transmitted Fungal Contamination in Different Wards of Kamkar Hospital in Qom Iran in 2007. Qom Univ Med Sci J. 2009;3(3):25-30.

16. Dales RE, Zwanenburg H, Burnett R, Franklin CA. Respiratory health effects of home dampness and molds among Canadian children. Am JEpidemiol. 1991;134(2):196-203.

17. Mandal J, Brandl H. Bioaerosols in indoor environment-a review with special reference to residential and occupational locations. Open Environ B Monitoring J. 2011;4:83-96.

18. Zeini F, Emami M. Medical Mycology. 2004.

19. Botelho AM, Nunes Zd, Asensi MD, Gomes MZ, Fracalanzza SE Figueiredo AM. Characterization of coagulase-negative staphylococci isolated from hospital indoor air and a comparative analysis between airborne and inpatient isolates of Staphylococcus epidermidis. J Med Microbiol. 2012;61(Pt 8):1136-45.

20. Panagopoulou P, Filioti J, Petrikkos G, Giakouppi P, Anatoliotaki M, Farmaki E, et al. Environmental surveillance of filamentous fungi in three tertiary care hospitals in Greece. $J$ Hosp Infect. 2002;52(3):185-91.

21. Sautour M, Sixt N, Dalle F, L'Ollivier C, Fourquenet V, Calinon C, et al. Profiles and seasonal distribution of airborne fungi in indoor and outdoor environments at a French hospital. Sci Total Environ. 2009;407(12):3766-71.

22. Marcelou Kinti U. Study of the Mycological Flora of the Air Role in Mycosis of the Conjunctiva. Del Ellen Microbial Etai.1977;22(3):159163.

23. Okhuoya JA, Okaraedge SO. Microflora of road side air and leaf surfaces of selected vegetables. Nigerian J Pure Appl Am Sci. 1992;12:42-48. 